\title{
TRACER STUDY PROGRAM STUDI DIPLOMA III AKUNTANSI FEB UNRAM TAHUN 2019
}

\author{
Robith Hudaya \\ Fakultas Ekonomi dan Bisnis Universitas Mataram \\ robith.hudaya@gmail.com
}

\begin{abstract}
ABSTRAK
Program Studi DIII Akuntansi Fakultas Ekonomi dan Bisnis Universitas Mataram telah meluluskan ribuan mahasiswa sejak berdirinya pada tahun 1997, namun tracer study belum pernah dilakukan selama ini, sehingga Program Studi DIII Akuntansi Fakultas Ekonomi dan Bisnis Universitas Mataram memandang perlu dilakukannya tracer study secara berkala (setiap tahun). Tracer study berguna untuk memantau lulusan dan mengetahui relevansi kompetensi lulusan Program Studi DIII Akuntansi dengan kebutuhan stakeholder. maka perumusan masalah dalam penelitian ini dapat dirangkum sebagai berikut: 1).Bagaimana penilaian stakeholders terhadap kinerja alumni?; 2).Berapa lama masa tunggu alumni sampai mendapatkan pekerjaan pertamanya? 3).Bagaimanakah relevansi antara kurikulum dengan kebutuhan stakeholders?. Jenis penelitian ini adalah penelitian deskriptif. Penelitian ini memberikan gambaran mengenai lulusan dan kompetensi lulusan Program Studi DIII Akuntansi Fakultas Ekonomi dan Bisnis Universitas Mataram yang dibutuhkan oleh stakeholder. Berdasarkan hasil pembahasan dapat ditarik simpulan sebagai berikut: 1).Kinerja alumni Prodi DIII akuntansi menurut stakeholders adalah sangat baik; 2).Masa tunggu alumni sampai mendapatkan pekerjaan pertamanya adalah 2.4 bulan; 3).Relevansi antara kurikulum dengan kebutuhan stakeholder sudah cukup sesuai, yang bisa dilihat dengan layaknya lulusan Program Studi DIII Akuntansi untuk bekerja pada berbagai organisasi, baik swasta maupun pemerintahan. Selain itu, beberapa hal yang perlu rekonstruksi terhadap kurikulum yang bisa meningkatkan peningkatan kemampuan lulusan terutama terkait dengan bahasa inggris, komputer akuntansi, soft skill dan kemampuan pendukung lainnya.
\end{abstract}

\section{Kata Kunci: Tracer Study; Stakeholders, Alumni}

\section{PENDAHULUAN}

\section{Latar Belakang}

Lulusan yang sesuai kebutuhan pengguna (stakeholders) merupakan tuntutan yang harus dipenuhi oleh program studi/jurusan. Sejalan dengan hal itu, program studi (jurusan) harus melakukan perbaikan kualitas proses akademik secara berkesinambungan. Salah satu upaya memperbaiki kualitas adalah dengan melakukan pengembangan kurikulum berbasis 
kompetensi berdasarkan kebutuhan pengguna. Hal ini sesuai dengan amanat Direktorat Jenderal Dikti yang tertuang dalam Buku Panduan Pengembangan Kurikulum Berbasis Kompetensi Pendidikan Tinggi (2008) dan diperkuat dengan pasal 6 ayat (2) dan Pasal 97 Peraturan Pemerintah No.17 Tahun 2010 tentang pengelolaan dan penyelenggaraan pendidikan.

Menurut Mukhtaruddin dan Andriani (1999) yang dikutip oleh Cahyaningtyas (2007), landasan yang paling mendasar dalam pembentukan seorang profesional yang berkualitas, mampu bersaing dan memiliki keunggulan kompetitif dibidang akuntansi, bisa dicapai melalui pendidikan tinggi akuntansi yang mampu berintegrasi dengan perubahan-perubahan yang terjadi. Lebih lanjut, hasil kajian yang dilakukan oleh IBE-UNESCO pada tahun 1998 yang tercantum dalam panduan pengembangan dan penyusunan Kurikulum Pendidikan Tinggi (KPT) Pendekatan Kurikulum Berbasis Kompetensi (KBK) dan Pendidikan Berbasis Capaian (PBC) (Dikti, 2012) menyatakan bahwa tuntutan kemampuan tenaga kerja terdidik didasarkan pada 4 (empat) pilar pendidikan yaitu (1) belajar untuk tahu (learning to know), (2) belajar untuk berbuat (learning to do) perubahan dari keahlian ke kompetensi, dematerialisasi pekerjaan dan naiknya sektor layanan (the rise of service sector), serta bekerja di bidang ekonomi informal, (3) belajar untuk hidup bersama (learning to live together), belajar untuk hidup dengan orang lain (learning to live with others) menemukan orang lain dan bekerja untuk tujuan bersama (discovering others and working toward common objectives), dan (4) belajar untuk menjadi (learning to be).

Selain empat pilar tersebut tuntutan atas kemampuan tenaga kerja terdidik sangat terkait dengan perubahan pada tatanan global. Pengembangan Sumber Daya Manusia (SDM) yang bermutu melalui penyelenggaraan pendidikan yang berkualitas diharapkan mampu meningkatkan daya saing bangsa di level nasional maupun internasional. Daya saing dapat ditingkatkan melalui peningkatan kualitas dan relevansi lulusan program studi. Hal ini menuntut penyelenggaraan pendidikan bertanggung jawab dengan memfasilitasi anak didik dengan ilmu pengetahuan, keterampilan serta nilai dan sikap untuk berkompetisi secara fair di dunia kerja. (Cahyaningtyas, 2007). Perpres No 12 tahun 2012 menyatakan bahwa, lulusan pendidikan tinggi harus memiliki kualifikasi yang levelnya sesuai dengan strata dan jenis pendidikannya. Hal yang sama dijelaskan juga dalam panduan pengembangan dan penyusunan pendidikan tinggi oleh Dikti (2012) bahwa kurikulum pencapaian akhir dari penguasaan kompetensi dalam pelatihan dan dunia kerja adalah untuk dapat bekerja sesuai dengan kebutuhan pekerjaan.

Penguasaan kompetensi lulusan yang sesuai dengan kebutuhan pekerjaan maupun stakeholders dapat diketahui dari tracer study. Tracer study berfungsi menyediakan informasi mengenai hubungan antara pendidikan tinggi dan dunia kerja profesional. Dengan demikian tracer study 
merupakan alat untuk menilai relevansi kurikulum pendidikan tinggi dengan kebutuhan stakeholders. Dilain pihak, tracer study memberikan informasi mengenai situasi transisi dan dinamika kerja dan sebagai salah satu persyaratan akreditasi.

Program Studi DIII Akuntansi Fakultas Ekonomi dan Bisnis Universitas Mataram telah meluluskan ribuan mahasiswa sejak berdirinya pada tahun 1997, namun tracer study belum pernah dilakukan selama ini, sehingga Program Studi DIII Akuntansi Fakultas Ekonomi dan Bisnis Universitas Mataram memandang perlu dilakukannya tracer study secara berkala (setiap tahun). Tracer study berguna untuk memantau lulusan dan mengetahui relevansi kompetensi lulusan Program Studi DIII Akuntansi dengan kebutuhan stakeholder.

\section{Perumusan Masalah}

Berdasarkan latar belakang, maka perumusan masalah dalam penelitian ini dapat dirangkum sebagai berikut:

1. Bagaimana penilaian stakeholders terhadap kinerja alumni?

2. Berapa lama masa tunggu alumni sampai mendapatkan pekerjaan pertamanya?

3. Bagaimanakah relevansi antara kurikulum dengan kebutuhan stakeholders?

\section{Tujuan dan Kegunaan Penelitian}

\section{Tujuan Penelitian}

Penelitian ini bertujuan untuk mengetahui:

1. Penilaian stakeholders terhadap kinerja alumni

2. Lama masa tunggu alumni sampai mendapatkan pekerjaan pertamanya

3. Relevansi antara kurikulum dengan kebutuhan stakeholders

\section{Kegunaan Penelitian}

Hasil penelitian ini diharapkan dapat digunakan untuk memperbaiki kurikulum Program Studi DIII Akuntansi Fakultas Ekonomi dan Bisnis Universitas Mataram terkait dengan kompetensi yang dibutuhkan oleh stakeholders minimal setiap 5 tahun sekali

\section{TINJAUAN PUSTAKA}

\section{Tracer Study}

Tracer study lulusan merupakan penelusuran lulusan untuk menggali informasi melalui pengisian kuesioner yang disusun sedemikian rupa untuk tujuan perbaikan kurikulum dan proses pendidikan di Program Studi DIII Akuntansi Fakultas Ekonomi dan Bisnis Universitas Mataram (Anonim, 2011). Menurut Schomburg (2003:11), tracer study merupakan studi mengenai lulusan lembaga penyelenggara pendidikan tinggi. Istilah lain 
yang juga sering digunakan adalah "Graduate Surveys", "Alumni Researches", dan "Follow-up Study". Istilah-istilah tersebut merujuk pada pengertian yang "hampir" sama dengan istilah tracer study yang untuk selanjutnya akan digunakan dalam panduan ini.

Tracer studi bertujuan untuk memperoleh informasi yang bermanfaat untuk mengevaluasi hasil pendidikan di Perguruan Tinggi. Informasi yang diperoleh dapat digunakan untuk mengembangkan institusi dalam konteks quality assurance. Selain itu juga tracer study berguna untuk memperoleh informasi mengenai kekurangan dari program pendidikan disuatu perguruan tinggi sehingga diperlukan rencana untuk aktivitas berikutnya. (Schomburg, 2003:11). Hal yang tidak jauh berbeda diungkapkan oleh Rahmadi (2012) bahwa tracer study mempunyai 4 manfaat penting, yaitu

1. Tidaklah terbatas pada perguruan tinggi saja, tetapi lebih jauh lagi dapat memberikan informasi penting mengenai hubungan (link) antara dunia pendidikan tinggi dengan dunia kerja.

2. Tracer study dapat menyajikan informasi mendalam dan rinci mengenai kecocokan/match kerja baik horisontal (antar berbagai bidang ilmu) maupun vertikal (antar berbagai level/strata pendidikan).

3. Tracer study dapat ikut membantu mengatasi permasalahan kesenjangan kesempatan kerja dan upaya perbaikannya. Bagi universitas, informasi mengenai kompetensi yang relevan bagi dunia kerja dapat membantu upaya perbaikan kurikulum dan sistem pembelajaran.

4. Di sisi lain, dunia industri dan dunia kerja dapat memantau ke dalam instistusi pendidikan tinggi melalui tracer study, dan dengan demikian dapat menyiapkan diri dengan menyediakan pelatihan-pelatihan yang lebih relevan bagi sarjana pencari kerja baru.

\section{Kompetensi}

Menurut Undang-Undang Republik Indonesia Nomor 20 Tahun 2003 Tentang Sistem Pendidikan Nasional mendefinisikan Kompetensi lulusan sebagai kualifikasi kemampuan lulusan yang mencakup sikap, pengetahuan, dan keterampilan sesuai dengan standar nasional yang telah disepakati. Pasal 27 ayat (2) PP no 19 tahun 2005 menyebutkan bahwa Standar Kompetensi Lulusan pendidikan tinggi yang ditetapkan oleh masing-masing Perguruan Tinggi adalah sebagai berikut: (1) Standar Kompetensi Lulusan bukan saja merupakan kompetensi mata pelajaran yang telah dirancang oleh program studi belaka tetapi juga mencakup sikap, pengetahuan dan keterampilan, (2) Standar Kompetensi Lulusan bertujuan mempersiapkan lulusan selain dapat menemukan, mengembangkan, menerapkan ilmu, teknologi, dan seni yang bermanfaat juga lulusan diharapkan berakhlak mulia dan mandiri (3) Standar Kompetensi Lulusan perguruan tinggi ditentukan oleh masing-masing perguruan tinggi. 
Menurut Departemen Pendidikan Nasional melalui Keputusan Menteri No. 232/U/2000 telah menetapkan bahwa program sarjana diarahkan pada hasil lulusan yang memiliki kualifikasi sebagai berikut :

1. Menguasai dasar-dasar ilmiah dan ketrampilan dalam bidang keahlian tertentu sehingga mampu menemukan, memahami, menjelaskan, dan merumuskan cara penyelesaian masalah yang ada di dalam kawasan keahliannya;

2. Mampu menerapkan ilmu pengetahuan dan keterampilan yang dimilikinya sesuai dengan bidang keahliannya dalam kegiatan produktif dan pelayanan kepada masyarakat dengan sikap dan perilaku yang sesuai dengan tata kehidupan bersama;

3. Mampu bersikap dan berperilaku dalam membawakan diri berkarya di bidang keahliannya maupun dalam berkehidupan bersama di masyarakat;

4. Mampu mengikuti perkembangan ilmu pengetahuan, teknologi, dan/atau kesenian yang merupakan keahliannya.

\section{Kualitas Lulusan}

Kualitas lulusan menjadi alat ukur keberhasilan suatu lembaga pendidikan dalam memenuhi tututan terhadap dunia. Kualitas lulusan dapat dilihat dari dua aspek, yaitu Output dan Outcome.

1. Output

a. Indeks Prestasi Komulatif (IPK)

Sistem Kredit Semester (SKS) mengenal dua jenis Indeks Prestasi yaitu Indeks Prestasi per Semester (IP) dan Indeks Prestasi Kumulatif (IPK), IP merupakan ukuran keberhasilan mahasiswa dalam menempuh mata ajar pada satu semester, sedangkan IPK adalah ukuran keberhasilan mahasiswa yang dihitung mulai masa awal studi sampai semester terakhir yang telah diikuti. IPK adalah jumlah perkalian nilai kredit dengan nilai bobot seluruh mata ajar dibagi dengan jumlah sks mata ajar yang diambil dalam kurun waktu tertentu.

Besarnya IP dan IPK dapat dihitung sebagai berikut :

$$
\begin{aligned}
I P & =\frac{\sum_{i=1}^{n} N_{i} K_{i}}{\sum_{i=1}^{n} N_{i}} \\
\mathrm{Ki} & =\text { Nilai konversi setiap mata kuliah } \\
I P & =\frac{\sum_{i=1}^{n} N_{i} K_{i}}{\sum N_{i} p}
\end{aligned}
$$

Keterangan:

$\mathrm{Ni}=$ bobot SKS setiap mata kuliah 
$\mathrm{Ki}=$ Nilai konversi setiap mata kuliah dengan ketentuan konversi:
$A=4$
$\mathrm{B}+\quad=3,5$
$\mathrm{B}=3$
$\mathrm{C}+=2,5$
$C=2$
$\mathrm{D}+=1,5$
$\mathrm{D}=1$
$\mathrm{E} \quad=0$
$\mathrm{Ni}, \mathrm{p}=$ Jumlah SKS mata kuliah yang diprogramkan sejak awal sampai semester yang bersangkutan tanpa nilai gagal (nilai huruf E).

b. Masa Studi, merupakan masa yang diperlukan oleh mahasiswa untuk menyelesaikan studi (kuliah). Masa studi dihitung sejak terdaftar menjadi mahasiswa sampai dengan ujian akhir (skripsi dan komprehensif). Masa studi untuk program DIII adalah 6 10 semester. Bila dalam masa studi 10 semester mahasiswa belum meraih ijazah, maka ia tidak diperkenankan melanjutkan studi di jurusan/program studi bersangkutan. Untuk ini telah dilakukan toleransi tertentu untuk kondisi /kasus keterlambatan tertentu sebelum DO. (Anonim, 2012)

c. Lama Waktu Tunggu Memperoleh Pekerjaan Pertama merupakan Waktu tunggu kerja (sejak wisuda sampai masuk kerja) lulusan

d. Besaran Gaji Pertama adalah besarnya gaji yang diterima pertama kali kerja oleh lulusan

2. Outcomes

Meningkatnya kepercayaan masyarakat yang disebabkan oleh kualitas lulusan (output) dengan indikator antara lain:

a. Jumlah peminat Program Studi DIII Akuntansi merupakan jumlah calon mahasiswa yang mendaftar di Program Studi DIII Akuntansi Fakultas Ekonomi dan Bisnis Universitas Mataram setiap penerimaan mahasiswa baru

b. Jumlah Pengguna lulusan adalah jumlah instansi (institusi) yang menggunakan lulusan Program Studi DIII Akuntansi Fakultas Ekonomi dan Bisnis Universitas Mataram sebagai pegawai (karyawan)

\section{METODE PENELITIAN}

\section{Jenis/Rancangan Penelitian}

Jenis penelitian ini adalah penelitian deskriptif. Penelitian ini memberikan gambaran mengenai lulusan dan kompetensi lulusan Program 
Studi DIII Akuntansi Fakultas Ekonomi dan Bisnis Universitas Mataram yang dibutuhkan oleh stakeholder.

\section{Populasi, Sampel dan Teknik Pengambilan Sampel}

Populasi dalam penelitian ini adalah semua alumni lulusan Program Studi DIII Akuntansi Fakultas Ekonomi dan Bisnis Universitas Mataram. Sampel penelitian adalah sampel populasi yaitu semua lulusan Program Studi DIII Akuntansi Fakultas Ekonomi dan Bisnis Universitas Mataram dari Tahun 2016 sampai dengan Tahun 2018.

\section{Prosedur Pengumpulan Data dan Sumber Data Prosedur Pengumpulan Data}

Pengumpulan data dilakukan dengan personally administrated questionnaires. Metode ini dilakukan melalui penyebaran kuesioner berupa daftar pertanyaan (kuesioner) kepada responden dengan pertanyaan terkait (angket terstruktur).

\section{Sumber Data}

Data penelitian ini bersumber dari data primer dan data sekunder, yaitu data yang bersumber dari data kuesioner dan data berupa dokumendokumen yang diarsip oleh Prodi D3 Akuntansi, seperti buku alumni dan lain sebagainya.

\section{Variabel Penelitian}

Variabel-variabel yang digunakan dalam penelitian ini adalah:

1. Indeks Prestasi Kumulatif merupakan ukuran keberhasilan mahasiswa yang dihitung mulai masa awal studi sampai semester terakhir yang telah diikuti yang dihitung dengan mengalikan nilai kredit dengan nilai bobot seluruh mata kuliah dibagi dengan jumlah sks mata kuliah yang diambil dalam kurun waktu tertentu

2. Masa Studi merupakan masa yang diperlukan oleh mahasiswa untuk menyelesaikan studi (kuliah). Masa studi dihitung sejak terdaftar menjadi mahasiswa sampai dengan ujian akhir (skripsi dan komprehensif)

3. Jumlah peminat program studi akuntansi merupakan jumlah calon mahasiswa yang mendaftar di Program Studi DIII Akuntansi Fakultas Ekonomi dan Bisnis Universitas Mataram setiap penerimaan mahasiswa baru

4. Lama Waktu Tunggu Memperoleh Pekerjaan Pertama merupakan Waktu tunggu kerja (sejak wisuda sampai masuk kerja) lulusan

5. Jenis Perusahaan / Institusi Pengguna Iulusan adalah jenis perusahaan ataupun instansi (institusi) yang menggunakan lulusan Program Studi DIII Akuntansi Fakultas Ekonomi dan Bisnis Universitas Mataram sebagai pegawai (karyawan) 
6. Besaran Gaji Pertama adalah besarnya gaji yang diterima pertama kali kerja oleh lulusan

7. Hubungan Program Studi dengan Pekerjaan Lulusan adalah keterkaitan keahlian lulusan Prodi D3 Akuntansi FEB Unram dengan jenis pekerjaan yang dijalankan oleh lulusan atau alumni.

8. Tingkat Pendidikan yang Paling Sesuai Dengan Pekerjaan Lulusan adalah tingkat pendidikan yang dianggap paling sesuai menurut lulusan dengan pekerjaan yang dijalani.

9. Jenis Beasiswa Lulusan Semasa di Program Studi DIII Akuntansi adalah jenis beasiswa yang pernah didapatkan oleh lulusan pada saat masih berstatus mahasiswa pada Prodi D3 Akuntansi FEB Unram.

\section{Prosedur Dan Analisis Data}

Prosedur dan analisis data dapat dilakukan dengan langkah-langkah sebagai berikut:

1. Data yang terkumpul selanjutnya ditabulasi dan dianalisis secara statistik deskriptif

2. Data yang dianalisis adalah data yang tidak null, walaupun beberapa analisis masih mengikutsertakan data seperti ini. Untuk saat ini belum dilakukan cross analysis untuk melihat keterkaitan antar data.

3. Hasil analisis dituangkan dalam bentuk laporan yang memuat informasi statistik dan rekomendasi.

\section{HASIL DAN PEMBAHASAN}

\section{Gambaran Umum Responden}

Responden pada tracer study kali ini adalah semua alumni dan pengguna Program Studi DIII Akuntansi Fakultas Ekonomi dan Bisnis Universitas Mataram dari Tahun 2016 sampai dengan pertengahan Tahun 2019. Namun dari semua responden, hanya 179 orang Alumni dan 88 penguna yang mengisi kuesioner yang disebarkan dengan periode wisuda 2016 - 2019, sehingga didapatkan 179 data alumni dan 98 data pengguna yang dapat digunakan sebagai dasar untuk menganalisis. 
Berikut ini adalah deskripsi responden berdasarkan jenis kelamin:

Tabel 1

Deskripsi Responden Alumni

\begin{tabular}{|c|c|c|}
\hline \multirow{2}{*}{$\begin{array}{c}\text { Tahun } \\
\text { (Yudisium/Wisuda) }\end{array}$} & \multicolumn{2}{|c|}{ Jenis Kelamin } \\
\cline { 2 - 3 } & $\mathbf{L}$ & $\mathbf{P}$ \\
\hline 2016 & 16 & 24 \\
\hline 2017 & 21 & 39 \\
\hline 2018 & 24 & 48 \\
\hline 2019 & 2 & 5 \\
\hline Jumlah (orang) & $\mathbf{6 3}$ & $\mathbf{1 1 6}$ \\
\hline Jumlah (\%) & $\mathbf{3 5 \%}$ & $\mathbf{6 5 \%}$ \\
\hline
\end{tabular}

Sumber : Data Primer Diolah (2019)

Tabel 1 menunjukkan dari 179 responden (alumni), 63 orang berjenis kelamin laki-laki dan 116 orang berjenis kelamin perempuan, atau $35 \%$ responden adalah berkelamin laki-laki, dan $65 \%$ responden berjenis kelamin perempuan.

Lulusan (alumni) Program Studi DIII Akuntansi berdasarkan periode tahun lulus (yudisium) ditunjukkan pada tabel 2 berikut:

Tabel 2

\section{Lulusan Prodi DIII Akuntansi Berdasarkan Periode Yudisium}

\begin{tabular}{|c|c|c|}
\hline Tahun Yudisium & Jumlah & $\mathbf{\%}$ \\
\hline 2016 & 40 & $22 \%$ \\
\hline 2017 & 60 & $34 \%$ \\
\hline 2018 & 72 & $40 \%$ \\
\hline 2019 & 7 & $4 \%$ \\
\hline Jumlah & $\mathbf{1 7 9}$ & $\mathbf{1 0 0}$ \\
\hline
\end{tabular}

\section{Sumber : Data Primer Diolah (2019)}

Berdasarkan Tabel 2 dapat dilihat responden terbanyak berasal dari angkatan wisuda tahun 2018, atau sebanyak 72 orang, dan jumlah terkecil berasal dari angkatan wisuda tahun 2009, yaitu berjumlah 7 orang, atau $4 \%$ dari total responden, hal ini disebabkan karena proses penyebaran kuisioner terlaksana pada pertengahan tahun 2019 yaitu tepatnya pada bulan Mei hingga bulan Juni 2019. Sementara periode penyebaran kuisioner tersebut baru terlaksana wisuda periode pertama pada Tahun 2019.

\section{Analisis Data}

Penelitian ini adalah penelitian deskriptif sedangkan analisisnya menggunakan tabulasi dengan memberikan penjelasan atas tabulasi tersebut dan rekomendasi terkait dengan variabel yang digunakan. Adapun variabel yang akan dianalisis adalah output dan outcomes karena 2 variabel tersebut adalah pengukur keberhasilan lembaga pendidikan dalam 
memenuhi kebutuan stakeholder. Output diukur dengan Indeks Prestasi Komulatif (IPK), masa studi, Lama Waktu Tunggu Memperoleh Pekerjaan Pertama dan Besaran Gaji. Outcomes diukur dengan jumlah peminat Prodi DIII akuntansi dan pengguna lulusan akuntansi.

\section{Input (Jenis Beasiswa Yang Pernah Didapatkan Lulusan di Prodi D3 Akuntansi)}

Pada Program Studi Diploma 3 (D3) Akuntansi rutin membuka dua (2) jenis beasiswa setiap tahunnya. Yaitu Beasiswa jalur prestasi yang disitilahkan dengan beasiswa PPA dan beasiswa untuk mahasiswa kurang mampu yang sering diistilahkan dengan beassiswa BBM. Namun demikian beberapa mahasiswa yang lulus seleksi masuk Prodi D3 juga mendapatkan beasiswa yang diadakan dari Pemerintah Pusat seperti Beasiswa Adik; Beasiswa Bidikmisi; Beasiswa Afirmasi. Berikut adalah data mahasiswa yang yang mendapatkan beasiswa, baik dari program pemerintah Pusat maupun dari Prodi D3 Akuntansi sendiri:

\section{Tabel 3.}

Prosentase Penerima Beasiswa Tahun 2016 - 2019

\begin{tabular}{|l|l|c|l|}
\hline No & Jenis Beasiswa & Jumlah & Prosentase \\
\hline 1 & Beasiswa Adik & 01 orang & $0.56 \%$ \\
\hline 2 & Beasiswa Bidikmisi & 11 orang & $6.15 \%$ \\
\hline 3 & Beasiswa PPA & 14 orang & $7.82 \%$ \\
\hline 4 & Beasiswa Afirmasi & 01 orang & $0.56 \%$ \\
\hline 5 & Tdk mendapatkan beasiswa & 152 orang & $84.91 \%$ \\
\hline & Jumlah & 179 orang & $100 \%$ \\
\hline
\end{tabular}

Sumber: Data Primer Diolah (2019)

\section{Output}

\section{Indeks Prestasi Kumulatif (IPK)}

Indeks Prestasi Komulatif (IPK) merupakan ukuran keberhasilan (nilai) mahasiswa yang dihitung mulai sejak menempuh studi pertama kali sampai semester terakhir yang diakhiri dengan PKL dan Ujian Laporan PKL. IPK tertinggi adalah 4 dengan skala $0-4$. Semakin tinggi IPK mahasiswa maka tingkat keberhasilan untuk menerima materi yang disampaikan Dosen semakin tinggi dan sebaliknya. IPK alumni Program Studi DIII akuntansi periode wisuda 2016 - 2019 dapat dilihat pada tabel 4 berikut: 


\section{Tabel 4}

IPK Alumni Program Studi DIII Akuntansi Periode Wisuda 2016 2019

\begin{tabular}{|c|c|c|}
\hline No. & $\begin{array}{c}\text { Tahun } \\
\text { (Yudisium/Wisuda) }\end{array}$ & $\begin{array}{c}\text { IPK (Rata- } \\
\text { Rata) }\end{array}$ \\
\hline 1 & 2016 & 3,26 \\
\hline 2 & 2017 & 3,07 \\
\hline 3 & 2018 & 3,22 \\
\hline 4 & 2019 & 2.93 \\
\hline & Rata-Rata & $\mathbf{3 , 1 2}$ \\
\hline
\end{tabular}

Sumber : Data Primer Diolah (2019)

Berdasarkan hasil pada tabel 4 dapat dilihat bahwa IPK tertinggi diperoleh mahasiswa yang yudisium (wisuda) pada tahun 2016 dengan IPK rata-rata 3,26 dan IPK terendah pada mahasiswa yang yudisium tahun 2019 yaitu rata-rata 2,93 . Secara keseluruhan IPK rata-rata alumni masih di atas 3 (sangat memuaskan) yaitu 3,12.

\section{Masa Studi}

Masa studi merupakan waktu yang diperlukan oleh mahasiswa untuk menyelesaikan studi (kuliah) yang dihitung sejak terdaftar menjadi mahasiswa sampai dengan menyelesaikan PKL dan Ujian Laporan PKL. Semakin cepat masa studi maka semakin baik. Masa studi normal untuk Prodi DIII adalah selama 36 bulan (6 semester).

Masa studi alumni Prodi DIII akuntansi periode wisuda 2016 - 2019 dapat dilihat pada tabel 5 berikut:

\section{Tabel 5}

\section{Masa Studi Alumni Program Studi DIII Akuntansi Periode Wisuda} 2016 - 2019

\begin{tabular}{|c|c|c|}
\hline No. & $\begin{array}{c}\text { Tahun } \\
\text { (Yudisium/Wisuda) }\end{array}$ & $\begin{array}{c}\text { Masa Studi } \\
\text { (bulan) }\end{array}$ \\
\hline 1 & 2016 & 35 \\
\hline 2 & 2017 & 35 \\
\hline 3 & 2018 & 35 \\
\hline 4 & 2019 & 38 \\
\hline & Rata-Rata & $\mathbf{3 5 , 7 5}$ \\
\hline
\end{tabular}

\section{Sumber : Data Primer Diolah (2019)}

Hasil tabel 5 menjelaskan bahwa masa studi paling lama adalah mahasiswa yang yudisium (wisuda) pada tahun 2019 yaitu 39 bulan, sedangkan masa studi paling cepat adalah mahasiswa yang yudisium tahun 2016, 2017 dan 2018 yaitu 35 bulan. Secara keseluruhan, mahasiswa akuntansi yang wisuda periode 2016 - 2019 masa studi rata-rata adalah 35,75 bulan. 


\section{Masa Tunggu Untuk Mendapatkan Pekerjaan Utama}

Lama waktu tunggu memperoleh pekerjaan pertama merupakan merupakan waktu tunggu untuk memperoleh pekerjaaan pertama kali sejak sejak wisuda. Semakin cepat waktu tunggu untuk memperoleh pekerjaan pertama menunjukkan daya serap lulusan dimanfaatkan oleh pihak eksternal semakin bagus. Waktu tunggu alumni Program Studi DIII akuntansi periode wisuda 2016 - 2019 dapat dilihat pada tabel 6 berikut:

\section{Tabel 6}

Waktu Tunggu Alumni Prodi DIII Akuntansi Periode Wisuda 2002 $-2016$

\begin{tabular}{|c|c|c|}
\hline No. & $\begin{array}{c}\text { Tahun } \\
\text { (Yudisium/Wisuda) }\end{array}$ & $\begin{array}{c}\text { Waktu Tunggu } \\
\text { (Bulan) }\end{array}$ \\
\hline 1 & 2016 & 1.6 bulan \\
\hline 2 & 2017 & 3.3 bulan \\
\hline 3 & 2018 & 2.2 bulan \\
\hline 4 & 2019 & 2.7 bulan \\
\hline & Rata-Rata & 2.4 bulan \\
\hline
\end{tabular}

\section{Sumber : Data Primer Diolah (2016)}

Berdasarkan hasil pada tabel 6 dapat dilihat bahwa waktu tunggu paling lama untuk memperoleh pekerjaan pertama adalah mahasiswa yang yudisium (wisuda) pada tahun 2017 yaitu dengan waktu 3.3 bulan dan waktu tunggu tercepat untuk memperoleh pekerjaan pertama adalah mahasiswa yang yudisium tahun 2016 yaitu hanya 1.6 bulan. Secara keseluruhan waktu tunggu rata-rata alumni memperoleh pekerjaan pertama adalah 2.4 bulan.

\section{Pekerjaan Sambilan Yang Dimiliki Lulusan dan Besaran Penghasilannya}

Pekerjaan sambilan yang dimiliki lulusan maksudnya adalah adakah lulusan memiliki pekerjaan lain yang menjadi pekerjaan sampingan selain pekerjaan utama yang dimiliki oleh alumni tersebut. Dan berdasarkan data yang diperoleh, ternyata tidak sedikit alumni yang memiliki pekerjaan sampingan selain pekerjaan utamanya tersebut. Pekerjaan sampingannya ini kebanyakan bergelut di bidang jualan online.pekerjaan ini cukup menjanjikan dan tidak mengganggu jam pekerjaan utama tentunya. Oleh karena itu tidak heran jika jualan online ini dipilih sebagai pekerjaan alternative untuk menambah penghasilan. Berdasarkan hasil tabulasi kuisioner, teridentifikasi bahwa dari 179 orang sekitar 90 orang memiliki pekerjaan sampingan, dengan besaran penghasilan bervariasi dari Rp. 500.000 - Rp. 10.000.000 bergantung besarnya usaha yang dimiliki.

Besaran Gaji Yang Diperoleh Lulusan dari Pekerjaan Utama 
Besaran gaji pertama adalah besarnya gaji yang diterima saat pertama kali bekerja oleh alumni program studi DIII akuntansi. Besaran gaji pertama untuk ke 179 responden tersebut dapat dilihat pada tabel 7 berikut:

Tabel 7

Besaran Gaji Alumni Prodi DIII Akuntansi Periode Wisuda 2016 2019

\begin{tabular}{|c|l|c|c|}
\hline No. & \multicolumn{1}{|c|}{ Gaji } & Jumlah & \% \\
\hline 1 & Kurang dari Rp 1.000.000 & 27 & $15.08 \%$ \\
\hline 2 & Rp 1.000.000 - Rp 3.000.000 & 118 & $65.92 \%$ \\
\hline 3 & Rp 3.000.000 - Rp 5.000.000 & 34 & $19.00 \%$ \\
\hline 4 & Rp 5.000.000 - Rp 7.500.000 & 0 & $0 \%$ \\
\hline 5 & Rp 7.500.000 - Rp 10.000.000 & 0 & $0 \%$ \\
\hline 6 & Lebih dari Rp 10.000.000 & 0 & $0 \%$ \\
\hline & Total & 179 & $100 \%$ \\
\hline
\end{tabular}

Sumber : Data Primer Diolah (2019)

Berdasarkan hasil pada tabel 7 dapat dilihat bahwa besarnya gaji yang diterima oleh alumni Prodi DIII Akuntansi pada waktu pertama kali bekerja setelah lulus (wisuda) sebanyak 27 orang $(15.08 \%)$ memperoleh gaji di bawah Rp 1.000.000, 118 orang (65.92\%) dengan penghasilan Rp 1.000 .000 - Rp 3.000.000, 34 orang (19.00\%) dengan penghasilan $\mathrm{Rp}$ 3.000 .000 - Rp 5.000.000, dan 0 orang $(0 \%)$ dengan penghasilan $R p$ 5.000.000 - Rp 7.500.000. Hasil ini menunjukkan bahwa sebagian besar alumni mengutamakan pengalaman kerja dibandingkan dengan besaran gaji yang diterima.

\section{Hubungan Antara Bidang Studi dengan Pekerjaan Lulusan}

Hubungan antara bidang studi dengan pekerjaan lulusan, maksudnya adalah untuk melihat seberapa erat hubungan antara Bidang Studi dengan pekerjaan yang dijalankan oleh lulusan saat ini. Apakah sangat erat, erat, cukup erat, kurang erat atau bahkan tidak ada hubungan sama sekali. Dan berdasarkan tabulasi data yang ada, dari 179 responden terdapat $35(19,55 \%)$ lulusan memiliki pekerjaan yang sangat erat kaitannya dengan Bidang Studi Akuntansi, 32 (17,88\%) orang memiliki pekerjaan yang erat hubungannya dengan bidang studi akuntansi, 81 $(45,25 \%)$ lulusan memiliki pekerjaan yang cukup erat kaitannya dengan bidang studi akuntansi, 17 (9,50\%) orang memiliki pekerjaan yang kurang erat hubungannya dengan bidang studi akuntansi, dan 14 (7,82\%) orang 
memiliki pekerjaan yang tidak ada hubungannya sama sekali dengan bidang studi akuntansi.

\section{Tingkat Pendidikan Yang Paling Sesuai Dengan Pekerjaan Lulusan}

Pada kuisioner juga menanyakan kepada lulusan (alumni) terkait dengan tingkat Pendidikan yang paling tepat/ paling sesuai untuk pekerjaan yang sedang dijalankan sekarang. Apakah jenjang Pendidikan yang dibutuhkan setingkat lebih tinggi, tingkat yang sama, atau tidak perlu Pendidikan tinggi. Dan berdasarkan hasil tabulasi jawaban responden bahwa dari 179 orang responden, ada $39(21.79 \%)$ orang menyatakan bahwa tingkat Pendidikan yang paling sesuai dengan pekerjaan yang dijalankan sekarang adalah setingkat lebih tinggi dari jenjang pendidikan D3, dengan kata lain untuk pekerjaan yang dijalankan sekarang ini sebenarnya dibutuhkan Pendidikan paling rendah setara Sarjana Strata -1 (S1). Hal ini juga menjelaskan bahwa sebanyak $21,79 \%$ lulusan D3 Akuntansi Unram bisa bersaing dengan jenjang Pendidikan yang setingkat lebih tinggi dari jenjang diploma. Sebanyak 113 (63,13\%) alumni menyatakan bahwa pekerjaan yang mereka jalankan sekarang ini sudah sesuai dengan jenjang pendidikannya, yaitu prodi D3 Akuntansi. selain itu sebanyak $27(15,08 \%)$ orang menyatakan bahwa pekerjaan yang dijalankan sekarang ini tidak butuh Pendidikan yang tinggi, dengan kata lain sebanyak 15,08\% lulusan D3 Akuntansi Unram tidak bisa menerapkan ilmu yang dimilikinya pada bidang pekerjaan yang dijalankan.

\section{Outcomes}

Kepercayaan instansi/institusi maupun masyarakat akan kualitas alumni (lulusan Program Studi DIII Akuntansi Universtias Mataram menyebabkan outcome atas lulusan itu sendiri semakin meningkat. Outcomes diukur dengan jumlah peminat Prodi DIII akuntansi dan pengguna lulusan.

\section{Jumlah Peminat Program Studi DIII Akuntansi}

Jumlah peminat Prodi DIII Akuntansi merupakan jumlah calon mahasiswa yang mendaftar di Program Studi DIII Akuntansi Fakultas Ekonomi dan Bisnis Universitas Mataram. Hasil yang diperoleh dari Rektorat Universitas Mataram menunjukkan bahwa jumlah peminat Prodi DIII akuntansi untuk tahun 2016 sebanyak 221 orang melalui jalur Mandiri. Dari jumlah tersebut, yang diterima menjadi mahasiswa Program Studi DIII Akuntansi adalah sebanyak 197 orang.

Berdasarkan jumlah peminat yang cukup besar tersebut, Program Studi DIII Akuntansi masih cukup diminati oleh masyarakat. Namun, dari segi tingkat keketatan persaingan yang hanya sebesar 1,12 orang, Progam Studi DIII Akuntansi belum bisa bersaing dengan perguruan tinggi besar lainnya di Indonesia. 


\section{Jenis Perusahaan/Instansi Tempat Lulusan Bekerja (Pengguna Lulusan)}

Pengguna lulusan merupakan instansi (institusi) yang menggunakan lulusan Program Studi DIII Akuntansi Fakultas Ekonomi Universitas Mataram sebagai pegawai (karyawan). Hasil kuisioner tentang pengguna lulusan dapat dilihat pada tabel 8 berikut ini:

\section{Tabel 8}

Pengguna Lulusan Program Studi DIII Akuntansi Periode Wisuda 2016-2019

\begin{tabular}{|c|l|c|c|}
\hline No. & Jenis Instansi/Usaha & Jumlah & $\mathbf{\%}$ \\
\hline 1 & Instansi Pemerintah & 38 & $21,23 \%$ \\
\hline 2 & Organisasi Non-Profit & 4 & $2,23 \%$ \\
\hline 3 & Perusahaan Swasta & 97 & $54,19 \%$ \\
\hline 4 & Wiraswasta & 18 & $10,06 \%$ \\
\hline 5 & Lainnya & 22 & $12,29 \%$ \\
\hline & Total & 179 & $100 \%$ \\
\hline
\end{tabular}

Sumber : Data Primer Diolah (2016)

Berdasarkan Tabel 8, dapat dilihat bahwa alumni Program Studi DIII Akuntansi terbanyak bekerja pada Perusahaan Swasta Jasa, yaitu sebanyak 97 orang $(54,19 \%)$, sebanyak 38 orang $(21,23 \%)$ bekerja pada Instansi Pemerintah, 4 orang $(2,23 \%)$ bekerja pada Organisasi Non-Profit atau Lembaga Swadaya Masyarakat, 18 orang $(10,06 \%)$ bekerja sebagai wiraswasta, dan sebanyak 22 oarang (12,29\%) ekerja pada bidang lainnya.

Jenis instansi/perusahaan tempat para alumni bekerja adalah seperti Perbankan, Instansi Pusat seperti Universitas Mataram, Badan Pertanahan Negara, Kepolisian, dan Perusahaan Financing, dan berbagai perusahaan swasta bonafid lainnya. Banyaknya instansi (institusi) yang menggunakan alumni Prodi DIII Akuntansi Unram menunjukkan bahwa alumni Prodi DIII Akuntansi Unram masih bisa bersaing dengan prodi lainnya dalam hal perekrutan karyawan di tempat-tempat yang bonafid yang ada di Nusa Tenggara Barat (NTB).

\section{Penilaian Stakeholder}

Stakeholder adalah lembaga atau institusi yang menggunakan alumni Program Studi DIII akuntansi sebagai karyawan. Dalam rangka menyesuaikan antara kebutuhan stakeholder dengan lulusan, maka program studi/jurusan harus memperbaiki kualitas dengan 
mengembangkan kurikulum berbasis kompetensi berdasarkan kebutuhan stakeholder.

Untuk menentukan nilai kriteria dan kategori dalam penilaian stakeholder ini dilakukan penilaian dengan menggunakan interval kelas dengan rumus sebagai berikut :

Interval Kelas $=\frac{\text { Nilai tertinggi }- \text { nilai terendah }}{\text { Jumlah Kelas }}$

Nilai skor tertinggi dalam penelitian ini adalah 4 dan nilai terendah adalah 1 yang berasal dari skala penilaian kuesioner, dan jumlah kelas adalah 4. Dengan demikian didapatkan : Interval Kelas $=\frac{4-1}{4}=0,75$

Rentang kriteria dan kategori sebagai panduan pengelompokan hasil penilaian dapat dilihat pada Tabel 9 berikut ini:

\section{Tabel 9}

Rentang Kriteria dan Kategori

Sebagai Panduan Pengelompokan Hasil Penilaian

\begin{tabular}{|c|c|c|}
\hline No & Interval Kriteria & Kinerja \\
\hline 1 & $3,25 \mathrm{~s} / \mathrm{d} 4$ & Sangat Baik \\
\hline 2 & $2.50 \mathrm{~s} / \mathrm{d}<3.25$ & Baik \\
\hline 3 & $1.75 \mathrm{~s} / \mathrm{d}<2.50$ & Cukup Baik \\
\hline 4 & $1 \mathrm{~s} / \mathrm{d}<1.75$ & Kurang Baik \\
\hline
\end{tabular}

Berikut ini adalah hasil penilaian kinerja dan kualitas alumni Program Studi DIII Akuntansi:

Tabel 10

Penilaian Kinerja Lulusan Program Studi DIII Akuntansi

Periode Wisuda 2016 - 2019

\begin{tabular}{|c|l|c|l|}
\hline No & \multicolumn{1}{|c|}{ Kriteria/Aspek } & $\begin{array}{r}\text { Nilai } \\
\text { Rata- } \\
\text { rata }\end{array}$ & \multicolumn{1}{|c|}{ Kinerja } \\
\hline 1 & Etika & 3,41 & Sangat Baik \\
\hline 2 & Keahlian Pada Bidang Ilmu & 3.10 & Baik \\
\hline 3 & Kemampuan Berbahasa Asing & 2.40 & Cukup Baik \\
\hline 4 & Penggunaan Teknologi Informasi & 3.60 & Sangat baik \\
\hline 5 & Kemampuan Berkomunikasi & 3.30 & Sangat Baik \\
\hline 6 & Kerjasama Tim & 3.30 & Sangat Baik \\
\hline 7 & Pengembangan Diri/Kreativitas & 3.10 & Baik \\
\hline
\end{tabular}

Sumber : Data Primer Diolah (2019)

Berdasarkan Tabel 9, stakeholder menilai alumni Prodi DIII Akuntansi berkinerja sangat baik. Untuk kriteria etika, penggunaan Teknologi, Kemampuan berkomunikasi ,dan kerjasama tim alumni dinilai sangat baik oleh para stakeholder. Yang perlu mendapatkan perhatian adalah pada 
kriteria kemampuan untuk berbahasa asing yang bernilai paling rendah, pada penilaian juga mendapatkan penilaian yang agak rendah dengan nilai rata-rata 2.40 dengan kriteria cukup baik. Selain itu juga yang perlu mendapatkan perhatian adalah kemampuan berkomunikasi dan kerjasama tim, dipandang masih perlu untuk ditingkatkan. Karena kedua kriteria ini mendapatkan nilai yang sedang yaitu berada pada angka 3.30 dengan kriteria Sangat Baik. Pada pertanyaan berbeda, secara keseluruhan, tingkat kepuasan stakeholder terhadap alumni Prodi DIII akuntansi menunjukkan bahwa stakeholder merasa cukup puas. Alumni Prodi DIII Akuntansi mempunyai tempat bagi stakeholder untuk dijadikan sebagai karyawan/pegawai di tempat mereka. Selain itu juga, stakeholder memberikan respon positif terhadap alumni Prodi DIII akuntansi. Hal ini terbukti dengan adamya permintaan alumni Prodi DIII akuntansi sebagai karyawan/pegawai di instansi mereka.

Tujuan dari tracer study ini sebenarnya untuk menyeimbangkan kurikulum yang ada di Prodi DIII akuntansi Universitas Mataram dengan kebutuhan pengguna (stakeholder). Kurikulum yang semakin mendekati kebutuhan stakeholder akan semakin baik dan ini membuktikan bahwa kurikulum tersebut sudah efektif. Salah satu cara untuk menggali hal tersebut adalah dengan menerima masukan dan saran dari stakeholder. Adapun saran dari stakeholder adalah :

1. Alumni Prodi DIII Akuntansi seharusnya memiliki kemampuan yang cukup terkait dasar-dasar akuntansi, dalam akuntansi perbankan, akuntansi sektor publik, dan menerapkannya dalam praktik, serta mampu membuat laporan keuangan seperti laporan bulanan dan tahunan, serta teliti dalam menghitung keuangan perusahaan.

2. Memiliki kesiapan bekerja, kesiapan mental, kesiapan fisik, handal, tangguh, percaya diri, dan berintegritas, disiplin dan cekatan.

3. Memiliki pengalaman berorganisasi, kemampuan untuk bekerja dalam tim dan mencapai target tertentu, kemampuan yang baik dalam hal public speech, dan memiliki kecerdasan spiritual yang tinggi.

4. Menguasai komputer akuntansi, percaya diri, jujur, konsisten

5. Memiliki kemampuan berbahasa asing terutama bahasa inggris, sehingga mampu memahami dan menyusun laporan keuangan menggunakan Bahasa Inggris.

6. Memiliki kemampuan untuk bekerja dengan tim.

Dalam pengelolaan Program Studi dan proses pembelajaran, stakeholder juga menyarankan agar adanya peningkatan sarana dan prasarana perkuliahan yang bisa menciptakan suasana yang kondusif bagi mahasiswa untuk mengikuti pembelajaran di kampus. Di samping itu, Program Studi juga dituntut untuk terus mengembangkan kerjasama dengan berbagai instansi dan perusahaan swasta, dalam penempatan magang, dan juga kerjasama untuk mempermudah penyerapan alumni Program Studi DIII Akuntansi di dunia kerja. 
Saran-saran yang diberikan oleh stakeholder seharusnya ditindaklanjuti oleh Program Studi DIII Akuntansi, dengan melakukan rekonstruksi kurikulum, penyusunan Rencana Perkuliahan Semester dan Rencana Tugas Mandiri yang disesuaikan dengan profil lulusan yang disesuaikan dengan keinginan stakeholder. Khusus untuk mata kuliah bahasa Inggris umum maupun special purpose untuk ekonomi dan bisnis serta komputer akuntansi dengan excel akuntansi maupun software akuntansi yang lainnya harus ditingkatkan dalam praktik

Untuk mata kuliah tertentu akan diberikan porsi praktik (latihan) maupun kasus yang lebih banyak seperti Pengantar Akuntansi dan Akuntansi Keuangan, Auditing dan Akuntansi untuk Koperasi dan UMKM, Akuntansi Perbankan Konvensional, Akuntansi Sektor Publik. Hal yang sangat perlu diperhatikan oleh Prodi DIII Akuntansi adalah peningkatan soft skillantara lain kemampuan bekerjasama, kemampuan berkomunikasi, jujur dan disiplin. Peningkatan soft skill ini biasanya ada pada mata kuliah seminar dan mata kuliah perilaku organisasi yang menekankan kemampuan berkomunikasi. Kejujuran dan disiplin itu ditekankan pada mata kuliah Agama dan semua mata kuliah.

Peningkatan sarana dan prasarana harus ditingkatkan, seperti dengan adanya pengadaan komputer yang memadai secara spesifikasi untuk praktik, ruang kelas yang nyaman dan sebagainya. Kerjasama dengan berbagai pihak, juga harus terus ditingkatkan, dengan mengintensifkan program praktik kerja lapangan dan meningkatkan kerjasama yang telah dibina selama ini, untuk memudahkan penyaluran alumni sebagai tenaga kerja pada perusahaan/instansi.

\section{Interpretasi}

Relevansi atau tidaknya kurikulum suatu jurusan dapat dinilai dengan tracer study. Tracer study memberikan informasi terkait kompetensi lulusan yang sesuai dengan kebutuhan pekerjaan maupun stakeholders. Kompetensi lulusan dapat dilihat dari Indeks Prestasi Komulatif. Semakin tinggi IPK mahasiswa maka tingkat keberhasilan untuk menerima materi yang disampaikan Dosen semakin tinggi dan sebaliknya. Hasil penelitian menunjukkan IPK rata-rata alumni Prodi DIII Akuntansi sebesar 3,17 (sangat memuaskan), jika dilihat dari IPK minimum untuk memperoleh pekerjaan terutama PNS sudah memenuhi syarat. Hal ini menunjukkan bahwa lulusan Prodi DIII Akuntansi layak untuk dijadikan pegawai/karyawan di instansi swasta maupun negeri karena dari segi pemahaman materi sudah baik.

Masa studi menurut hasil penelitian menunjukkan masa studi rata-rata adalah 35,69 bulan. Hasil ini memberikan informasi bahwa masa studi lulusan masih baik, karena kurang dari 36 bulan sebagai masa pendidikan normal. Dilihat dari masa tunggu untuk memperoleh pekerjaan pertama sekitar 5,15 bulan dengan gaji paling banyak berkisar pada Rp 1.000.000 - 
Rp 3.000.000. Hasil ini menunjukkan bahwa sebagian besar alumni Prodi DIII akuntansi lebih mengutamakan pengalaman kerja dibandingkan dengan gaji.

\section{SIMPULAN, KETERBATASAN DAN SARAN}

\section{Simpulan}

Berdasarkan hasil pembahasan pada bab 4 dapat ditarik simpulan sebagai berikut:

1. Kinerja alumni Prodi DIII akuntansi menurut stakeholders adalah baik.

2. Masa tunggu alumni sampai mendapatkan pekerjaan pertamanya adalah 5,15 bulan

3. Relevansi antara kurikulum dengan kebutuhan stakeholder sudah cukup sesuai, yang bisa dilihat dengan layaknya lulusan Program Studi DIII Akuntansi untuk bekerja pada berbagai organisasi, baik swasta maupun pemerintahan. Selain itu, beberapa hal yang perlu rekonstruksi terhadap kurikulum yang bisa meningkatkan peningkatan kemampuan lulusan terutama terkait dengan bahasa inggris, komputer akuntansi, soft skill dan kemampuan pendukung lainnya.

\section{Keterbatasan}

Selama penelitian ini, hanya sedikit responden dalam tracer study ini yang mengembalikan kuesioner sehingga tidak mencerminkan keadaaan alumni yang sebenarnya dan pada akhirnya tidak bisa digeneralisasi. Di samping itu, keterbatasan waktu untuk menunggu kembalinya kuisioner yang telah disebar kepada para responden.

\section{Saran}

Keterbatasan yang dialami selama penelitian dapat dijadikan masukan untuk tracer study berikutnya. Tracer study berikutnya, kuesioner lebih banyak disebarkan ke semua wilayah di Propinsi Nusa Tenggara Barat bahkan kalau perlu ke luar daerah dimana alumni tersebut bekerja dan memanfaatkan sosial media serta email sebagai sarana penyebaran kuesioner.

\section{DAFTAR PUSTAKA}

Anonim. 2000. Keputusan Menteri Pendidikan Nasional Republik Indonesia Nomor 232/U/2000 Tentang Pedoman Penyusunan Kurikulum Pendidikan Tinggi Dan Penilaian Hasil Belajar Mahasiswa Menteri Pendidikan Nasional.

2005. Peraturan Pemerintah Republik Indonesia Nomor 19 Tahun 2005 Tentang Standar Nasional Pendidikan 
. 2010. Peraturan Pemerintah No.17 Tahun 2010 tentang pengelolaan dan penyelenggaraan pendidikan

. 2011. Manual Prosedur Tracer Study Fakultas Pertanian Universitas Brawijaya Malang. https://www.google.com/url?sa=f\&rct=j\&url=http://gjm.fp.ub.ac.id/ documents/doc/tracer study.pdf\&q=\&esrc=s\&ei=HeGNUYLNFMPprQ fAmYDgCQ\&usg=AFQjCNGJmzYdAqp3U6eMplLgJi9KypXPaw.

Diunduh tanggal 11 Mei 2013

Mataram

Budi, Bambang, Setia. Hanson, Endra, Kusuma. Odah. 2012. Report 2012. Tracer Study dan Kepuasan Pengguna. ITB Career Center Lembaga Kemahasiswaan. karir.itb.ac.id. diunduh tanggal 11 Mei 2013

Cahyaningtyas, Susi Retna. Ali, Fikri. Siti, Atikah. Wahidatul, Husnaini. Lukman, Effendy. 2012. Analisis Keberagaman Karya Tulis IImiah dan Masa Studi sebagai Cermin Proses Pendidikan Pada Jurusan Akuntansi. Laporan Penelitian Dana BOPTN Universitas Mataram.

Cahyaningtyas, Susi. Retna Siti, Atikah. Wahidatul, Husnaini. 2008. Pengembangan Kurikulum Akuntansi (Strata satu) ke Arah Dunia Kerja Pada Program Studi Akuntansi Fakultas Ekonomi Universitas Mataram. Laporan Penelitian Dosen Muda Dikti.

Cahyaningtyas, Susi Retna. 2007. Penerapan Kurikulum Berbasis Kompetensi Pada Kurikulum Program Studi Akuntansi Strata satu (S1) Dalam Rangka Meningkatkan Mutu Pendidikan Perguruan Tinggi (Studi Kasus Pada Universitas Gadjah Mada, Universitas Surabaya, dan STIE PERBANAS Surabaya). Thesis. Unpublished. Pascasarjana Universitas Airlangga, Surabaya.

Dikti. 2012. panduan pengembangan dan penyusunan Kurikulum Pendidikan Tinggi (KPT) Pendekatan Kurikulum Berbasis Komptensi (KBK) dan Pendidikan Berbasis Capaian (PBC).

- 2008. Buku Panduan Pengembangan Kurikulum Berbasis Kompetensi Pendidikan Tinggi

Mukhtaruddin dan Andriani. 1999. Persepsi Mahasiswa Akuntansi Di PalembangTerhadap Rekayasa Kurikulum Akuntansi 1991. Simposium Nasional Akuntansi II. Malang.

Rahmadi. 2012. Ayo Partisipasi Dalam Tracer Study UI 2012. http://cdc.ui.ac.id/index.php?option=com content\&task=view\&id=77 8\&Itemid=121. Diunduh tanggal 11 Mei 2013

Syamsudin, Amir. Muthmainnah dan Rina, Wulandari. 2006. Laporan Penelusuran Alumni Program Studi D-II PGTK FIP UNY. https://www.google.com/search?sclient=psy$a b \& q=$ proposal + tracer+study\&oq = proposal +tracer+study\&gs $\mid=$ ser p.3..6614035.6619803.0.6620152.21.15.0.0.0.0.0.0..0.0...0.0...1c.1. 12.psyab.CgpjfRQiaZw\&pbx $=1 \&$ bav $=0$. 2 , or. $r$ cp.r qf.\&biw $=1024 \& b$ 
ih $=630 \&$ ech $=1$ \&psi $=a$ G2MUZPNcWkrQfPo4FA. $1368157722608.3 \& \mathrm{em}$

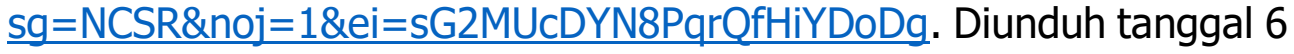
Mei 2013

Yusuf, Rusli. T.M. Iqbalsyah. Asep, Rusyana. Taufik, F. Abidin. Syaiful, Bahri. Rika, Marlia. Irvanizam. Sayed, Muchallil. Emi, Nurmasyitah. 2012. Tracer Study Unsyiah 2012 Transisi Dari Dunia Kampus ke Dunia Kerja. Universitas Syiah Kuala 